\title{
Comparison of the results of the treatment of enophthalmos in orbital blowout fracture in children/adolescents and adults
}

\author{
Piotr Koryczan ${ }^{A-F}$, Jan Zapała ${ }^{A-F}$, Michał Gontarz ${ }^{A-F}$, Grażyna Wyszyńska-Pawelec ${ }^{A-F}$ \\ Department of Cranio-Maxillofacial Surgery, Jagiellonian University Medical College, Kraków, Poland \\ A - research concept and design; $B$ - collection and/or assembly of data; $C$ - data analysis and interpretation; \\ $D$ - writing the article; $E$ - critical revision of the article; $F$ - final approval of the article
}

Address for correspondence

Grażyna Wyszyńska-Pawelec

E-mail: grazyna.wyszynska-pawelec@uj.edu.pl

Funding sources

None declared

Conflict of interest

None declared

Received on August 29, 2020

Reviewed on 0 ctober 4, 2020

Accepted on November 24, 2020

Published online on May 24, 2021

Cite as

Koryczan P, Zapała J, Gontarz M, Wyszyńska-Pawelec G.

Comparison of the results of the treatment of enophthalmos

in orbital blowout fracture in children/adolescents and adults.

Dent Med Probl. 2021;58(2):179-186. doi:10.17219/dmp/130815

DOI

$10.17219 / \mathrm{dmp} / 130815$

Copyright

○) 2021 by Wroclaw Medical University

This is an article distributed under the terms of the

Creative Commons Attribution 3.0 Unported License (CC BY 3.0)

(https://creativecommons.org/licenses/by/3.0/).

\section{Abstract}

Background. Orbital fractures are common injuries in adults and children. Although the mechanism of blowout fracture is generally similar regardless of age, due to differences in anatomy, clinical symptoms of these fractures vary in the 2 groups of patients. Numerous articles describe the methods of orbital reconstruction leading to enophthalmos correction; however, the current literature lacks articles presenting the comparison of enophthalmos treatment results in adults and children with orbital blowout fracture.

Objectives. The aim of this study was to compare the results of the treatment of enophthalmos in orbital blowout fracture in children/adolescents and adults with regard to the location of the fracture, the time from the injury to surgical treatment, the type of surgical procedure, and the donor location of an autogenous bone graft.

Material and methods. The treatment results of 2 groups were compared: 530 adults (patients over 18 years of age; $18-77$ years; average age: 34 years); and 200 children/adolescents (4-18 years; average age: 12.1 years). Data was obtained retrospectively through a review of the medical history of patients treated for a fracture of the orbital floor and/or medial wall in our department in the years 1975-2015.

Results. In patients with post-traumatic enophthalmos, the correct positioning of the eyeball was achieved in 313 adults (59.1\%) and 139 children (69.5\%), improvement in 159 adults (30\%) and 49 children (24.5\%), and no improvement in 58 adults (10.9\%) and 12 children (6\%). Recovery after surgical treatment was achieved in 311 adults (60.9\%) and 94 children (52.8\%), improvement in 120 adults (23.5\%) and 59 children (33.1\%), and no improvement in 80 adults (15.7\%) and 25 children (14\%).

Conclusions. The relationship between post-traumatic enophthalmos and the location of the fracture was more significantly marked in the adult group. In cases that required bone graft reconstruction, better results were achieved in adults.

Keywords: enophthalmos, orbital blowout fracture, orbital fracture, diplopia 


\section{Introduction}

In adults as well as in children, orbital fractures are quite common among the injuries of the facial part of the skull. Depending on classification (isolated fractures of the orbit, or part of maxillo-zygomatic or naso-orbital fractures), orbital fractures constitute $4-50 \%$ of fractures. ${ }^{1-3}$ Pure orbital blowout fracture is defined as a fracture of the orbital floor and/or medial wall with intact margins of the orbit. Enophthalmos is one of the main symptoms accompanying orbital fracture. Enophthalmos greater than $2 \mathrm{~mm}$ is clinically detectable, and may lead to esthetic and functional disorders (Fig. 1, Fig. 2, Fig. 3). As part of orbital fracture, enophthalmos may be a result of changes in the volume of the orbit, or muscle and/or fat atrophy due to ischemia. Numerous articles describe the methods of orbital reconstruction leading to postoperative enophthalmos correction; however, the current literature lacks articles presenting the comparison of enophthalmos treatment results in adults and children with orbital blowout fracture. Isolated fracture of the orbital floor, owing to its pathomechanism, is limited to the orbital

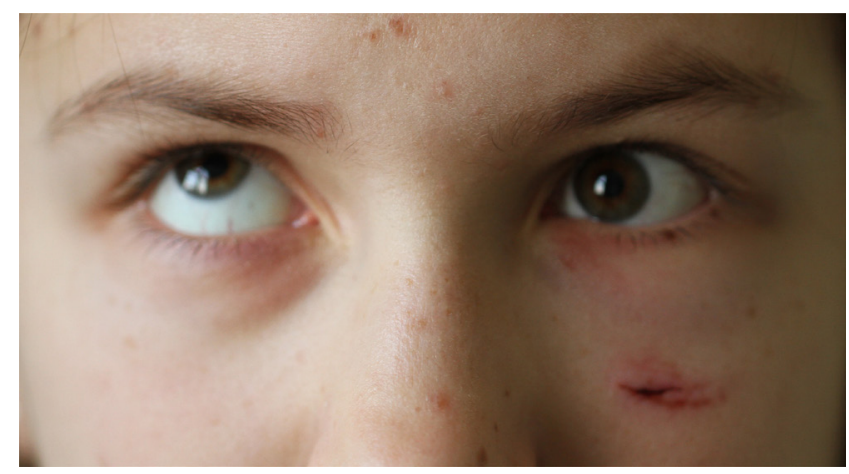

Fig. 1. Girl with blowout fracture of the left orbit and enophthalmos

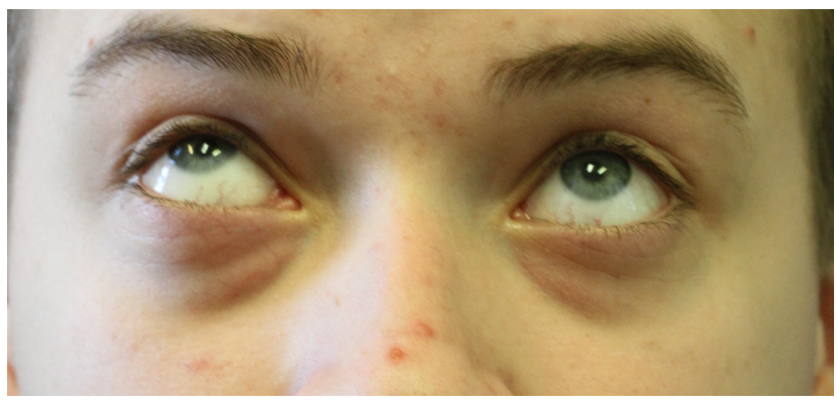

Fig. 2. Patient with blowout fracture of the left orbit and enophthalmos

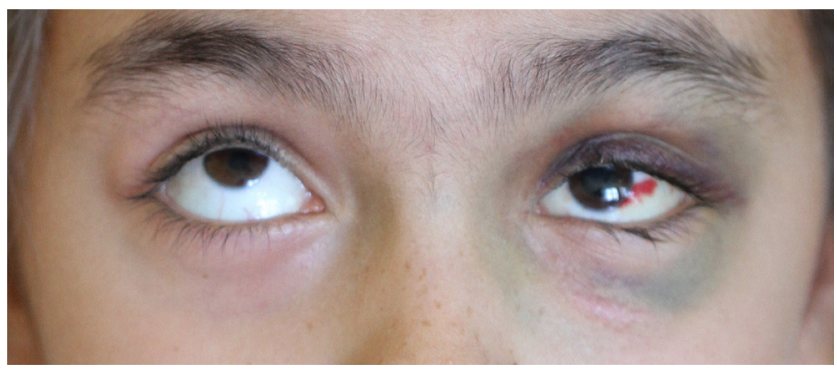

Fig. 3. Girl with blowout fracture of the left orbit and enophthalmos area, and its characteristic symptoms are unique to this type of facture. Due to differences in the proportions of the facial and cerebral parts of the skull, the degree of paranasal sinus development, and the flexibility of the bone, the appearance of orbital blowout fracture in adults and children varies. ${ }^{4,5}$ Typical symptoms of pure blowout fracture of the orbit include diplopia, enophthalmos and the lack of sensation in the suborbital area, usually accompanied by soft tissue swelling. In the case of orbital fracture in pediatric patients, limited eyeball movement is predominant, very often with the lack of or very discreet symptoms of soft tissue swelling. ${ }^{6}$ In adults, blowout fracture with the loss of bony structures of the orbital floor or medial wall, and the herniation of periocular tissues into the maxillary or ethmoid sinus is quite common. ${ }^{7}$ In contrast, white-eyed fracture, which is very often not evident in the images of the bone fracture, and the predominant impairment of eyeball movement is quite typical in children. ${ }^{8-12}$ Due to its location and symptoms, orbital blowout fracture often requires collaboration among clinical teams, consisting of ophthalmologists, radiologists and maxillofacial surgeons. ${ }^{13-18}$

\section{Objectives}

The aim of this study was to compare the results of enophthalmos treatment in orbital blowout fracture in children/adolescents and adults with regard to the location of the fracture, the time from the injury to surgical treatment, the type of the surgical procedure used, and the site of autogenous bone graft harvest.

\section{Material and methods}

The treatment results of the following 2 groups were compared: adults (patients over 18 years of age; 18-77 years; average age: 34 years) and children/adolescents (4-18 years; average age: 12.1 years). Data was obtained retrospectively through a review of the medical history of patients treated for a fracture of the orbital floor and/or medial wall in our department between 1975 and 2015. The study included patients with pure orbital blowout fracture without a coexisting fracture of other parts of the facial skeleton (Fig. 4). Data on enophthalmos was obtained from the records of ophthalmological examinations, which had been carried out at the beginning of treatment, after surgery, and repeatedly, depending on indications, during postoperative observation in the outpatient mode. Similarly, data on diplopia was obtained. Double vision was evaluated on a 5-point scale: in upgaze (type I), in upgaze and downgaze (type II), in straight and upgaze (type III), in straight and downgaze (type IV), or in the whole scope of view (type V). The indications for surgical treatment in both groups were as follows: persistent double vision with no tendency to subside; limited mobility of the eyeball; enophthalmos above $2 \mathrm{~mm}$; and an extensive fracture of the orbital floor and/or medial wall. 


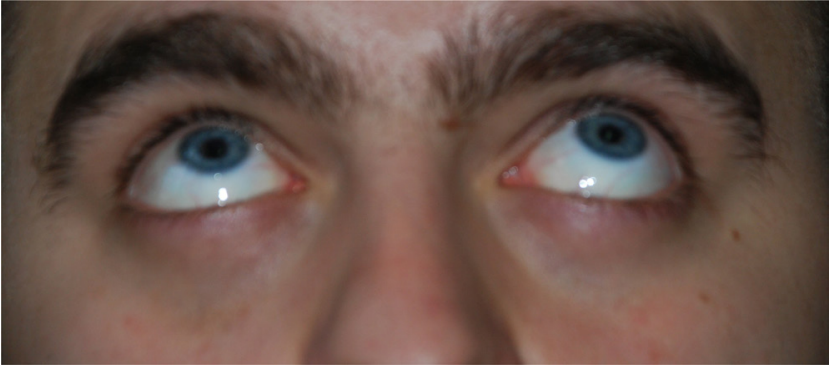

Fig. 4. Patient with blowout fracture of the right orbit

Surgical procedures included the revision of the fracture site with the removal of the herniated tissues in the case of linear fractures, or revision combined with tissue release and defect reconstruction with autogenous bone transplantation in fractures with a bone defect. The procedures were performed under general anesthesia. Passive eye movement was tested (the forced duction test) at the beginning and end of the procedure. The access of choice was the transconjunctival incision, or in the case of fracture with soft tissue damage around the injury, access through the wound.

The following recovery criteria were selected: the lack of diplopia; full eyeball movement; and enophthalmos lesser than $1 \mathrm{~mm}$. Improvement was defined as a decrease in enophthalmos after the surgical procedure, a reduction in the area of diplopia and improvement in eyeball movement. The lack of improvement was indicated by persistent diplopia, and no improvement in enophthalmos and eyeball movement.

\section{Statistical analysis}

The statistical analysis was performed in R, v. 3.6.1. (the $\mathrm{R}$ Foundation, the $\mathrm{R}$ Project for Statistical Computing; https://www.R-project.org/). The relationships between the scales were analyzed using the $X^{2}$ test and differences between the groups were evaluated using the $\chi^{2}$ test with Bonferroni's correction. In addition, the Kruskal-Wallis tests were performed for the ranking scales referring to the time from trauma to surgery and enophthalmos after trauma, and Dunn's test with Bonferroni's correction and the Jonckheere-Terpstra trend test were used to compare both groups. A $p$-value less than 0.05 was considered statistically significant and a $p$-value less than 0.01 was considered highly significant.

\section{Results}

In the adult group, the most common cause of injury was an assault - 265 patients (50\%), followed by a fall - 88 patients $(16.6 \%)$. In the child group, the most common causes of injury were an accidental hit to the periorbital area -74 children (37\%), and sports -47 children (23.5\%). Individual causes of injury in the adult and child groups are presented in Table 1.
Table 1. Characteristics of the study groups

\begin{tabular}{|c|c|c|c|}
\hline Characteristic & $\begin{array}{l}\text { Children/ } \\
\text { adolescents } \\
N=200\end{array}$ & $\begin{array}{l}\text { Adults } \\
N=530\end{array}$ & $p$-value \\
\hline $\begin{array}{l}\text { Sex } \\
\text { female } \\
\text { male }\end{array}$ & $\begin{array}{r}38(19.0) \\
162(81.0)\end{array}$ & $\begin{array}{r}90(16.9) \\
440(83.1)\end{array}$ & 0.596 \\
\hline $\begin{array}{l}\text { Cause of injury } \\
\text { assault } \\
\text { fall } \\
\text { accidental hit to the periorbital area } \\
\text { road traffic accident } \\
\text { sports } \\
\text { work accident } \\
\text { other }\end{array}$ & $\begin{array}{l}35(17.5) \\
19(9.5) \\
74(37.0) \\
17(8.5) \\
47(23.5) \\
0(0.0) \\
8(4.0)\end{array}$ & $\begin{array}{r}265(50.0) \\
88(16.6) \\
65(12.3) \\
49(9.2) \\
35(6.6) \\
14(2.6) \\
14(2.6)\end{array}$ & $<0.001^{*}$ \\
\hline $\begin{array}{l}\text { Location of fracture } \\
\text { floor } \\
\text { floor and medial wall } \\
\text { medial wall }\end{array}$ & $\begin{array}{l}176(88.0) \\
14(7.0) \\
10(5.0)\end{array}$ & $\begin{array}{l}434(81.9) \\
77(14.5) \\
19(3.6)\end{array}$ & $0.018^{*}$ \\
\hline $\begin{array}{l}\text { Enophthalmos after injury [mm] } \\
\text { vs location of fracture } \\
\text { floor } \\
\text { floor and medial wall } \\
\text { medial wall }\end{array}$ & $\begin{array}{c}1.15 \pm 0.95 \\
(n=176) \\
0.36 \pm 0.50 \\
(n=14) \\
0.40 \pm 0.52 \\
(n=10)\end{array}$ & $\begin{array}{c}1.53 \pm 1.21 \\
(n=434) \\
1.91 \pm 1.41 \\
(n=77) \\
0.37 \pm 0.68 \\
(n=19)\end{array}$ & $\begin{array}{c}0.001^{*} \\
\text { (children/ } \\
\text { adolescents) } \\
<0.001^{*} \\
\text { (adults) }\end{array}$ \\
\hline $\begin{array}{l}\text { Type of fracture intraoperatively } \\
\text { with a bone defect } \\
\text { linear }\end{array}$ & $\begin{array}{l}N=178 \\
129(72.5) \\
49(27.5)\end{array}$ & $\begin{array}{r}N=511 \\
438(85.7) \\
73(14.3)\end{array}$ & $<0.001^{*}$ \\
\hline $\begin{array}{l}\text { Diplopia } \\
\text { after injury } \\
\text { - lack of diplopia } \\
\text { - diplopia } \\
\text { after treatment } \\
\text { - lack of diplopia } \\
\text { - diplopia } \\
\text { after injury } \\
\text { - type I } \\
\text { - type II } \\
\text { - type III } \\
\text { - type IV } \\
\text { - type V } \\
\text { after treatment } \\
\text { - type I } \\
\text { - type II } \\
\text { - type III } \\
\text { - type IV } \\
\text { - type V }\end{array}$ & $\begin{array}{c}24(12.0) \\
176(88.0) \\
119(59.5) \\
81(40.5) \\
21(11.9) \\
43(24.4) \\
14(8.0) \\
5(2.8) \\
93(52.8)\end{array}$ & $\begin{array}{c}67(12.6) \\
463(87.4) \\
341(64.3) \\
189(35.7) \\
121(26.1) \\
119(25.7) \\
38(8.2) \\
46(9.9) \\
139(30.0) \\
\\
95(50.3) \\
55(29.1) \\
10(5.3) \\
22(11.6) \\
7(3.7)\end{array}$ & 0.914 \\
\hline $\begin{array}{l}\text { Enophthalmos } \\
\text { after injury } \\
\quad-0 \mathrm{~mm} \\
-1 \mathrm{~mm} \\
-2 \mathrm{~mm} \text { or more } \\
\text { after treatment } \\
-0 \mathrm{~mm} \\
-1 \mathrm{~mm} \\
-2 \mathrm{~mm} \text { or more }\end{array}$ & $\begin{aligned} 139(69.5) \\
49(24.5) \\
12(6.0)\end{aligned}$ & $\begin{array}{l}128(24.2) \\
134(25.3) \\
268(50.6)\end{array}$ & $<0.001^{*}$ \\
\hline $\begin{array}{l}\text { General symptoms } \\
\text { loss of consciousness } \\
\text { cerebral concussion } \\
\text { brain contusion } \\
\text { nausea and headache }\end{array}$ & $\begin{aligned} 31 & (15.5) \\
32 & (16.0) \\
3 & (1.5) \\
72 & (36.0)\end{aligned}$ & $\begin{array}{c}94(17.7) \\
96(18.1) \\
11(2.1) \\
104(19.6)\end{array}$ & $\begin{array}{c}0.545 \\
0.575 \\
0.768 \\
<0.001^{*}\end{array}$ \\
\hline
\end{tabular}

* statistically significant.

Data presented as number (percentage) $(n(\%))$ or as mean \pm standard deviation $(M \pm S D)$. 
The most common location of the fracture was the orbital floor, which regarded 434 patients $(81.9 \%)$ in the adult group and 176 patients (88\%) in the child group. Individual fracture locations are presented in Table 1. The relationship between the location of the fracture and post-traumatic enophthalmos was assessed. In the adult group, the greatest enophthalmos occurred in the case of a fracture of the orbital floor and medial wall, in contrast to the child group, where the greatest enophthalmos occurred with a fracture of the orbital floor. The results for individual groups are presented in Table 1. In the adult group, 438 patients (85.7\%) had an orbital fracture with a bone defect and $73(14.3 \%)$ had a linear fracture. In the child group, a fracture with a bone defect occurred in 129 patients (72.5\%), others had a linear fracture of the orbital floor. Individual types of fractures are presented in Table 1.

The injury was connected with the loss of consciousness in 94 patients $(17.7 \%)$ in the adult group and 31 patients (15.5\%) in the child group, cerebral concussion occurred in 96 patients $(18.1 \%)$ and 32 patients $(16 \%)$ in the adult and child groups, respectively, and 11 adults (2.1\%) and 3 children (1.5\%) suffered from brain contusion. Other general symptoms, such as nausea and headache, occurred in 104 adults (19.6\%) and 72 children (36\%).

The relationship between the time from the injury to surgery and the treatment outcome was evaluated. In surgically treated patients, 311 adults (60.9\%) and 94 children (52.8\%) were cured, 120 adults (23.5\%) and 59 children (33.1\%) showed improvement, while 80 adults $(15.7 \%)$ and 25 children (14\%) showed no improvement. In the adult group, a significant relationship between the time from the injury to surgery and the treatment outcome was found $(p<0.001)$. In general, the time from the injury to surgical treatment was shorter in the complete recovery group as compared to the improvement and no improvement groups. In the child group, no significant relationship between the time from the injury to surgery and the treatment outcome was found $(p=0.598)$. The results are presented in Table 2 and Table 3.
Post-traumatic enophthalmos occurred in 402 adults (75.8\%) and 132 children (66\%). Enophthalmos ranged from $1 \mathrm{~mm}$ to $6 \mathrm{~mm}$. After treatment, the proper positioning of the eyeball (enophthalmos less than or equal to $1 \mathrm{~mm}$ ) was achieved in 313 adults (59.1\%) and 139 children (69.5\%), improvement was observed in 159 adults (30\%) and 49 children (24.5\%), and there was no improvement in 58 adults (10.9\%) and 12 children (6\%). Changes in the size of enophthalmos were compared with respect to the type of surgical treatment that was used. In the group which underwent bone graft reconstruction, enophthalmos after injury was generally greater than in the group in which tissue release was used. A statistically significant relationship was found $(p<0.05)$. A reduction in enophthalmos was more significant in the bone graft reconstruction group. No statistically significant difference was observed between those 2 surgical methods in the child group. The results are summarized in Table 4 and Table 5.

Table 4. Relationship between a decrease in enophthalmos and the type of the surgical procedure applied in the adult group $(N=511)$

\begin{tabular}{|l|c|c|c|c|}
\hline \multirow{2}{*}{$\begin{array}{c}\text { Type of surgical } \\
\text { procedure }\end{array}$} & \multicolumn{3}{|c|}{$\begin{array}{c}\text { Decrease in enophthalmos } \\
\text { [mm] }\end{array}$} & \multirow{2}{*}{$p$-value } \\
\cline { 2 - 4 } & $M \pm S D$ & Me & quartiles & \\
\hline $\begin{array}{l}\text { Tissue release } \\
N=54\end{array}$ & $0.57 \pm 0.60$ & 1 & $0-1$ & \\
$\begin{array}{l}\text { Bone graft reconstruction } \\
N=457\end{array}$ & $1.08 \pm 1.03$ & 1 & $0-2$ & \\
\hline
\end{tabular}

M - mean; SD - standard deviation; Me - median; * statistically significant.

Table 5. Relationship between a decrease in enophthalmos and the type of the surgical procedure applied in the child group $(N=178)$

\begin{tabular}{|l|c|c|c|c|}
\hline \multirow{2}{*}{$\begin{array}{l}\text { Type of surgical } \\
\text { procedure }\end{array}$} & \multicolumn{3}{|c|}{$\begin{array}{c}\text { Decrease in enophthalmos } \\
\text { [mm] }\end{array}$} & -value \\
\cline { 2 - 4 } & $M \pm S D$ & Me & quartiles & \\
\hline $\begin{array}{l}\text { Tissue release } \\
N=46\end{array}$ & $0.80 \pm 0.75$ & 1 & $0-1$ & \\
$\begin{array}{l}\text { Bone graft reconstruction } \\
N=132\end{array}$ & $0.77 \pm 0.78$ & 1 & $0-1$ & \\
\hline
\end{tabular}

Table 2. Relationship between the time from the injury to surgical treatment and the treatment outcome in the adult group $(\mathrm{N}=511)$

\begin{tabular}{|c|c|c|c|c|c|c|c|}
\hline $\begin{array}{l}\text { Treatment } \\
\text { outcome }\end{array}$ & $\begin{array}{l}\text { On the day of accident } \\
\qquad N=8\end{array}$ & $\begin{array}{c}2-14 \text { days } \\
N=92\end{array}$ & $\begin{array}{c}15-30 \text { days } \\
N=202\end{array}$ & $\begin{array}{c}1-3 \text { months } \\
N=152\end{array}$ & $\begin{array}{c}\text { 4-6 months } \\
N=24\end{array}$ & $\begin{array}{l}>6 \text { months } \\
\qquad N=33\end{array}$ & $p$-value \\
\hline Complete recovery & $7(87.50)$ & $67(72.83)$ & $138(68.32)$ & $78(51.32)$ & $9(37.50)$ & $12(36.36)$ & \multirow{2}{*}{$<0.001^{*}$} \\
\hline No improvement & $0(0.00)$ & $9(9.78)$ & $25(12.38)$ & $28(18.42)$ & $10(41.67)$ & $8(24.24)$ & \\
\hline
\end{tabular}

* statistically significant.

Data presented as $n$ (\%).

Table 3. Relationship between the time from the injury to surgical treatment and the treatment outcome in the child group $(N=178)$

\begin{tabular}{|l|c|c|c|c|c|c|}
\multicolumn{1}{c|}{$\begin{array}{c}\text { Treatment } \\
\text { outcome }\end{array}$} & $\begin{array}{c}\text { On the day of accident } \\
N=4\end{array}$ & $\begin{array}{c}2-14 \text { days } \\
N=28\end{array}$ & $\begin{array}{c}15-30 \text { days } \\
N=70\end{array}$ & $\begin{array}{c}1-3 \text { months } \\
N=58\end{array}$ & $\begin{array}{c}4-6 \text { months } \\
N=11\end{array}$ & $\begin{array}{c}>6 \text { months } \\
N=7\end{array}$ \\
\hline Complete recovery & $1(25.00)$ & $16(57.14)$ & $37(52.86)$ & $34(58.62)$ & $5(45.45)$ & $1(14.29)$ \\
Improvement & $2(50.00)$ & $9(32.14)$ & $24(34.29)$ & $17(29.31)$ & $3(27.27)$ & $4(57.14)$ \\
No improvement & $1(25.00)$ & $3(10.71)$ & $9(12.86)$ & $7(12.07)$ & $3(27.27)$ & $2(28.57)$ \\
\hline
\end{tabular}

Data presented as $n(\%)$. 
The results of blowout fracture treatment in adults and children were compared with respect to the type of the surgical procedure used. Regardless of the type of surgery, similar effects were obtained in both adults and children. The results are presented in Table 6 and Table 7.

Table 6. Relationship between the type of the surgical procedure applied and the treatment outcome in the adult group $(N=511)$

\begin{tabular}{|c|c|c|c|}
\hline \multirow[b]{2}{*}{$\begin{array}{l}\text { Treatment } \\
\text { outcome }\end{array}$} & \multicolumn{2}{|c|}{ Type of surgical procedure } & \multirow[b]{2}{*}{$p$-value } \\
\hline & $\begin{array}{l}\text { tissue release } \\
\qquad N=54\end{array}$ & $\begin{array}{c}\text { bone graft } \\
\text { reconstruction } \\
N=457\end{array}$ & \\
\hline Complete recovery & $30(55.56)$ & $281(61.49)$ & \multirow{3}{*}{0.667} \\
\hline Improvement & $15(27.78)$ & $105(22.98)$ & \\
\hline No improvement & $9(16.67)$ & $71(15.54)$ & \\
\hline
\end{tabular}

Data presented as $n$ (\%).

The treatment outcome was assessed with respect to the site of autogenous bone graft harvest. In the adult group, the best results were obtained in the patients who underwent reconstruction with a donor graft taken from the anterior wall of the maxillary sinus, with $74 \%$ recovery, but in children, no statistically significant relationship was found. Detailed results for individual groups are presented in Table 8 and Table 9.
Table 7. Relationship between the type of the surgical procedure applied and the treatment outcome in the child group $(N=178)$

\begin{tabular}{|c|c|c|c|}
\hline \multirow[b]{2}{*}{$\begin{array}{l}\text { Treatment } \\
\text { outcome }\end{array}$} & \multicolumn{2}{|c|}{ Type of surgical procedure } & \multirow[b]{2}{*}{$p$-value } \\
\hline & $\begin{array}{l}\text { tissue release } \\
\qquad N=46\end{array}$ & $\begin{array}{l}\text { bone graft } \\
\text { reconstruction } \\
\quad N=132\end{array}$ & \\
\hline Complete recovery & $22(47.83)$ & $72(54.54)$ & \multirow{3}{*}{0.371} \\
\hline Improvement & $19(41.30)$ & $40(30.30)$ & \\
\hline No improvement & $5(10.87)$ & $20(15.15)$ & \\
\hline
\end{tabular}

Data presented as $n(\%)$.

Post-traumatic double vision occurred in 463 adults (87.4\%) and 176 children (88\%). In both adults and children, diplopia was most common in the entire field of view (type V) - 139 adults (30\%) and 93 children (52.8\%). Individual types of double vision are shown in Table 1 . The relationship between the diplopia type and the treatment outcome was assessed. In the adult group, the best outcomes were achieved in the case of type I diplopia (77.69\% recovery) and the worst in the case of type $\mathrm{V}$ (43.07\%). Type III diplopia was associated with the best prognosis in children (85.71\% recovery) and the worst results were obtained in the case of double vision in the entire scope of view (40.22\%). Detailed results are presented in Table 10 and Table 11.

Table 8. Relationship between the bone graft donor site and the treatment outcome in the adult group $(N=457)$

\begin{tabular}{|c|c|c|c|c|}
\hline \multirow[b]{2}{*}{ Treatment outcome } & \multicolumn{3}{|c|}{ Bone graft donor site } & \multirow[b]{2}{*}{$p$-value } \\
\hline & $\begin{array}{l}\text { iliac bone } \\
N=78\end{array}$ & $\begin{array}{l}\text { skull cover } \\
N=94\end{array}$ & $\begin{array}{l}\text { anterior wall of the maxillary sinus } \\
\qquad N=285\end{array}$ & \\
\hline Complete recovery & $39(50.00)$ & $31(32.98)$ & $211(74.04)$ & \multirow{3}{*}{$<0.001^{*}$} \\
\hline Improvement & $20(25.64)$ & $32(34.04)$ & $53(18.60)$ & \\
\hline No improvement & $19(24.36)$ & 31 (32.98) & $21(7.37)$ & \\
\hline
\end{tabular}

* statistically significant.

Data presented as number $n(\%)$.

Table 9. Relationship between the bone graft donor site and the treatment outcome in the child group $(N=132)$

\begin{tabular}{|c|c|c|c|c|}
\hline \multirow[b]{2}{*}{ Treatment outcome } & \multicolumn{3}{|c|}{ Bone graft donor site } & \multirow[b]{2}{*}{$p$-value } \\
\hline & $\begin{array}{l}\text { iliac bone } \\
N=42\end{array}$ & $\begin{array}{c}\text { skull cover } \\
N=47\end{array}$ & $\begin{array}{l}\text { anterior wall of the maxillary sinus } \\
\qquad N=43\end{array}$ & \\
\hline Complete recovery & $28(66.67)$ & $19(40.43)$ & $25(58.14)$ & \multirow{3}{*}{0.068} \\
\hline Improvement & $7(16.67)$ & $19(40.43)$ & $14(32.56)$ & \\
\hline No improvement & $7(16.67)$ & $9(19.15)$ & $4(9.30)$ & \\
\hline
\end{tabular}

Data presented as number $n(\%)$.

Table 10. Relationship between the type of post-traumatic diplopia and the outcome after surgical treatment in the adult group ( $N=511)$

\begin{tabular}{|l|c|c|c|c|c|c|c|}
\multicolumn{1}{c|}{$\begin{array}{c}\text { Treatment } \\
\text { outcome }\end{array}$} & $\begin{array}{c}\text { No diplopia } \\
N=53\end{array}$ & $\begin{array}{c}\text { Type I } \\
N=121\end{array}$ & $\begin{array}{c}\text { Type II } \\
N=118\end{array}$ & $\begin{array}{c}\text { Type III } \\
N=38\end{array}$ & $\begin{array}{c}\text { Type IV } \\
N=44\end{array}$ \\
\hline Complete recovery & $45(84.91)$ & $94(77.69)$ & $70(59.32)$ & $17(44.74)$ & $26(59.09)$ & $59(43.07)$ \\
Improvement & $6(11.32)$ & $15(12.40)$ & $25(21.19)$ & $19(50.00)$ & $10(22.73)$ & $45(32.85)$ \\
No improvement & $2(3.77)$ & $12(9.92)$ & $23(19.49)$ & $2(5.26)$ & $8(18.18)$ & $33(24.09)$ \\
\hline
\end{tabular}

* statistically significant.

Data presented as $n$ (\%). 
Table 11. Relationship between the type of post-traumatic diplopia and the outcome after surgical treatment in the child group $(N=178)$

\begin{tabular}{|l|c|c|c|c|c|c|c|}
\multicolumn{1}{c|}{$\begin{array}{c}\text { Treatment } \\
\text { outcome }\end{array}$} & $\begin{array}{c}\text { No diplopia } \\
N=4\end{array}$ & $\begin{array}{c}\text { Type I } \\
N=21\end{array}$ & $\begin{array}{c}\text { Type II } \\
N=43\end{array}$ & $\begin{array}{c}\text { Type III } \\
N=14\end{array}$ & $\begin{array}{c}\text { Type IV } \\
N=4\end{array}$ & $\begin{array}{c}\text { Type V } \\
N=92\end{array}$ & $p$-value \\
\hline $\begin{array}{l}\text { Complete recovery } \\
\text { Improvement }\end{array}$ & $0(0.00)$ & $16(76.19)$ & $26(60.47)$ & $12(85.71)$ & $3(75.00)$ & $37(40.22)$ & \\
No improvement & $2(50.00)$ & $4(19.05)$ & $11(25.58)$ & $2(14.29)$ & $1(25.00)$ & $39(42.39)$ & $0.005^{*}$ \\
\hline
\end{tabular}

* statistically significant.

Data presented as n (\%).

\section{Discussion}

Comparing the most common causes of orbital fracture in children and adults, there were some clear differences. In children, accidental hits to the periorbital area dominated, probably related to physical activity, which increases with the age of the child, and the $2^{\text {nd }}$ most common cause was an injury due to sport, which coincides with the results of other authors. ${ }^{8,9}$ In contrast, the main cause of injury in adults was an assault as a result of interpersonal violence. Road traffic accidents, which are often mentioned by other authors as the main cause of injury, ${ }^{19,20}$ ranked $4^{\text {th }}$ in the examined group.

Based on the available literature, intrabulbar injuries are associated with $3-18 \%$ of orbital fractures. ${ }^{13-18}$ In the child and adult groups, eyeball injuries constituted $6.5 \%$ and $16 \%$ of all cases, respectively; they were mainly cases of retinal concussion. In some cases, the rupture of the pupillary sphincter and anterior chamber hemorrhage were noted. In such situations, surgical treatment was postponed until symptoms subsided to avoid sight-threatening complications during the surgical procedure.

According to numerous authors, typical blowout fractures are quite rare in children and are dominated by trapdoor fractures. ${ }^{21-23}$ "A child is not a small adult" due to anatomical differences as well as differences in bone elasticity and periosteal thickness. In children, fractures with small displacement of hard tissue and a dominating picture of tissue herniation in the fracture area, with limited mobility of the eyeball, are often encountered, whereas in adults, due to fully developed paranasal sinuses, different proportions between the facial and cerebral parts of the skull, and thus greater exposure of the facial part to trau$\mathrm{ma}$, the most common orbital fracture is a fracture with tissue defects within the orbital floor. ${ }^{24,25}$ In our study groups, both children and adults presented with the typical picture of blowout fracture, regardless of age. It should be emphasized that the average age of children in our study was greater than 12 years, hence the type of fracture may differ from those in younger children. This is in line with the reports of other authors. ${ }^{26-28}$

Discussions on the most appropriate time interval between the injury and surgical treatment remain open. For children, the prevailing view is that the faster the treatment, the better the result. ${ }^{3,29,30}$ This scheme mainly applies to trapdoor fractures, in which prolonged entrapment of soft tissues, both muscle and intraorbital fat, can lead to irreversible changes, permanently impairing the mobility of the eyeball and resulting in permanent enophthalmos due to the atrophy of orbital fat. In adults, some authors point out that only the resolution of post-traumatic soft tissue edema allows for an accurate examination of enophthalmos and diplopia, and enables the proper qualification of the patient for conservative or surgical treatment. ${ }^{20,31}$ Exceptions to these patterns are a fracture with the occurrence of an oculo-cardiac reflex or the development of a retrobulbar hematoma, which may lead to post-traumatic optic neuropathy, requiring urgent surgical intervention. ${ }^{10,11,23}$ In our group of adults, there was a statistically significant relationship between the time from the injury to surgical treatment and the treatment outcome. The treatment results for the patients who underwent surgery up to 30 days after the injury were better than those of the patients who waited longer. There were no differences in the treatment outcomes in the patients who waited for treatment longer than 30 days after the injury (up to 3 months or more than 3 months after the injury). Missing the optimal time for surgical orbital reconstruction can lead to esthetic and functional disorders, such as permanent enophthalmos, eye globe depression and double vision. Postponed surgical treatment is intended for patients who develop double vision and enophthalmos later than 2 weeks after the injury as a result of orbital fibrosis. According to some authors, surgical reconstruction performed up to 14 days after the injury decreases the risk of late diplopia and enophthalmos. There was no statistically significant difference in the child group. Similar treatment effects were obtained regardless of the time from the injury to treatment; the only observed trend was better treatment outcome with earlier treatment.

Enophthalmos greater than $2 \mathrm{~mm}$ is clinically noticeable and, apart from being an esthetic defect, can cause functional disturbances in the form of double vision or impaired tear drainage., ${ }^{1,32}$ In the adult group, posttraumatic enophthalmos was more common, occurring in 402 adult patients (75.8\%), compared with 132 children (66\%). The goal of surgical treatment is to restore the proper position of the eyeball in the orbit, either by releasing the herniated tissues or restoring the continuity of the orbital walls to regain the proper function of the supporting structures of the eyeball (Fig. 5, Fig. 6, Fig. 7, Fig. 8). 


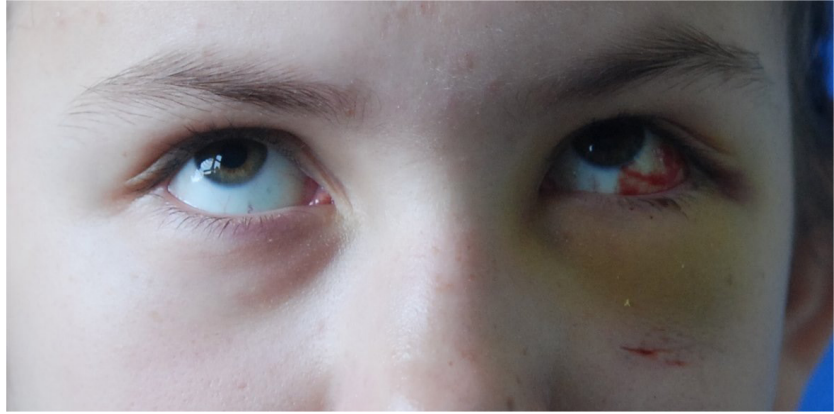

Fig. 5. The same girl as in Fig. 1, after surgery

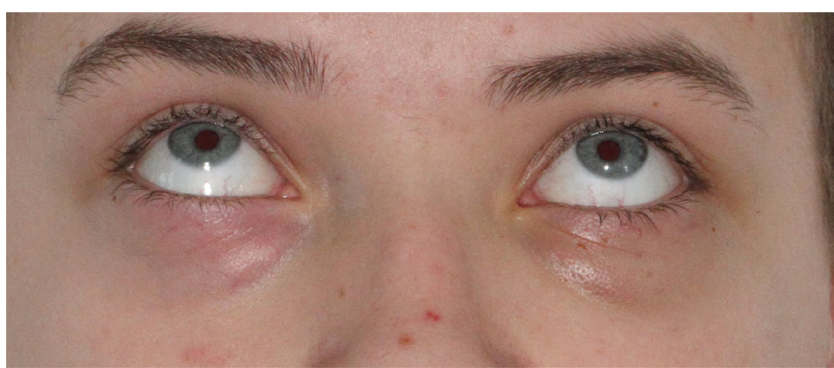

Fig. 6. The same patient as in Fig. 2, after surgery

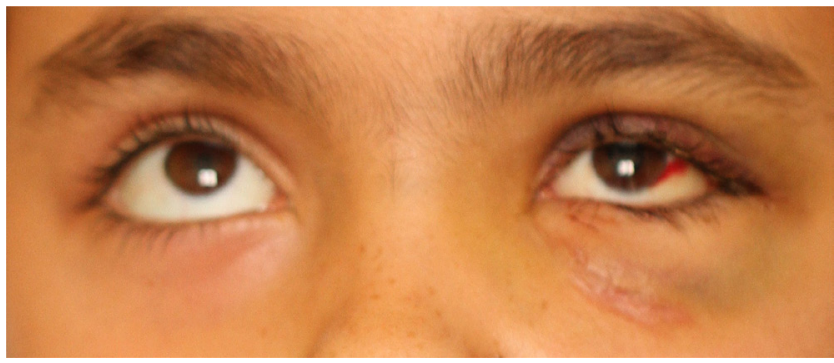

Fig. 7. The same girl as in Fig. 3, after surgery

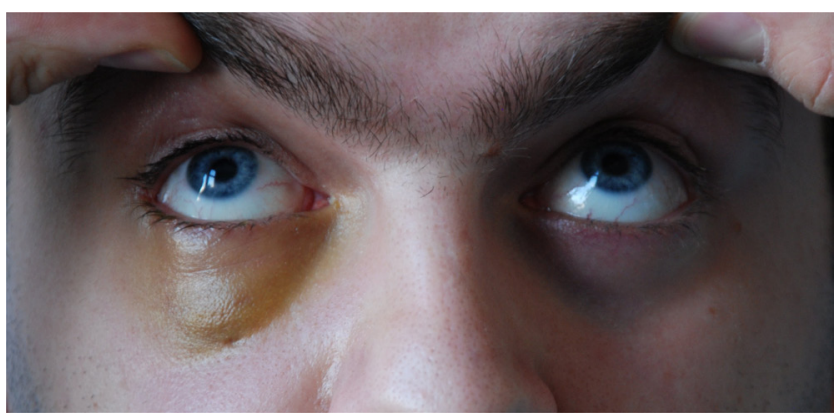

Fig. 8. The same patient as in Fig. 4, after surgery

According to Choi et al., patients with an orbital fracture involving the floor and medial wall are at greater risk of developing post-traumatic enophthalmos. ${ }^{33}$ This is mainly due to the loss of eyeball support in the lowermedial quadrant of the orbit. Fractures involving more than 1 orbital wall are also associated with a correspondingly greater disorder of the relationship between the orbital volume and the structures which make up its content. $^{34}$ These findings are consistent with the data from our adult group, in which the greatest enophthalmos was noted in the group with orbital floor and medial wall fractures. In contrast, in the child group, the greatest enophthalmos was associated with fractures of the orbital floor. In both groups there were differences in the incidence of enophthalmos, $75.8 \%$ of adult patients, compared with $66 \%$ of pediatric patients. Post-traumatic enophthalmos in orbital fracture may have different etiology - either changes in the orbital volume or the loss of periocular fat due to the entrapment of soft tissue in the fracture line. Various surgical methods have been described to restore the correct anatomy of the orbit, including reconstruction with the use of autoand xenografts as well as corrective osteotomies. ${ }^{33,35,36}$ Nowadays, in adults, orbital reconstruction with the use of titanium mesh, or patient-specific or customized implants is becoming more popular. ${ }^{37}$ In children, resorbable materials are widely used. In our groups of patients, an autogenous bone graft was the reconstruction material used in all patients who required the reconstruction of the orbital floor. In the adult group, the best results were obtained with the use of the anterior maxillary sinus wall graft, and in children, with grafts from the iliac bone; however, the most frequently used donor site was the skull. For children under 12-13 years of age, the use of a transplant from the anterior wall of the maxillary sinus is impossible due to the presence of permanent teeth buds. The use of autogenic orbital reconstruction material reduces the risk of inflammatory complications that may occur with artificial materials. The use of autogenic bone, despite inevitable and not completely predictable graft resorption, provides an opportunity to restore proper support for the eyeball, preventing the development of late enophthalmos.

\section{Conclusions}

The relationship between post-traumatic enophthalmos and the location of the fracture was more significantly marked in the adult group. After surgical treatment, the proper positioning of the eyeball (enophthalmos less than or equal to $1 \mathrm{~mm}$ ) was achieved in a similar percentage of patients in the adult and child groups. In cases requiring bone graft reconstruction, better results were achieved in the adult group. The causes of injury differed between adults and children. However, general symptoms accompanying the injury did not differ significantly between the 2 groups. Due to differences in the clinical picture of orbital floor fractures in children and adults, the diagnosis and treatment of orbital fracture in children may be more challenging.

\section{ORCID iDs}

Piotr Koryczan (D) https://orcid.org/0000-0002-9988-1869 Jan Zapała (1) https://orcid.org/0000-0002-5439-9614

Michał Gontarz (D) https://orcid.org/0000-0002-8180-948X

Grażyna Wyszyńska-Pawelec (D) https://orcid.org/0000-0001-7185-0633 


\section{References}

1. Bartoli D, Fadda MT, Battisti A, et al. Retrospective analysis of 301 patients with orbital floor fracture. J Craniomaxillofac Surg. 2015;43(2):244-247. doi:10.1016/j.jcms.2014.11.015

2. Scolozzi $P$, Jacquier $P$, Courvoisier DS. Can clinical findings predict orbital fractures and treatment decisions in patients with orbital trauma? Derivation of a simple clinical model. J Craniofac Surg. 2017;28(7):e661-e667. doi:10.1097/SCS.0000000000003823

3. Barh A, Swaminathan M, Mukherjee B. Orbital fractures in children: Clinical features and management outcomes. J AAPOS. 2018;22(6):415.e1-415.e7. doi:10.1016/j.jaapos.2018.07.353

4. Chukwulebe $S$, Hogrefe $C$. The diagnosis and management of facial bone fractures. Emerg Med Clin North Am. 2019;37(1):137-151. doi:10.1016/j.emc.2018.09.012

5. Wang NC, Ma L, Wu SY, Yang FR, Tsai YJ. Orbital blow-out fractures in children: Characterization and surgical outcome. Chang Gung Med J. 2010;33(3):313-320.

6. Wei LA, Durairaj VD. Pediatric orbital floor fractures. J AAPOS. 2011;15(2):173-180. doi:10.1016/j.jaapos.2011.02.005

7. Dubois L, Steenen SA, Gooris PJJ, Mourits MP, Becking AG. Controversies in orbital reconstruction - I. Defect-driven orbital reconstruction: A systematic review. Int J Oral Maxillofac Surg. 2015;44(3):308-315. doi:10.1016/j.ijom.2014.12.002.

8. Bansagi ZC, Meyer DR. Internal orbital fractures in the paediatric age group: Characterization and management. Ophthalmology. 2000;107(5):829-836. doi:10.1016/s0161-6420(00)00015-4

9. Jurdy L, Malhotra R. White-eyed medial wall blowout fracture mimicking head injury due to persistent oculocardiac reflex.J Craniofac Surg. 2011;22(5):1977-1979. doi:10.1097/SCS.0b013e31822eaa25

10. Mehmood N, Hasan A. Oculocardiac reflex: An underrecognized but important association with orbital trap door fractures. Pediatr Emerg Care. 2019. doi:10.1097/PEC.0000000000001884

11. Yew CC, Shaari R, Rahman SA, Alam MK. White-eyed blowout fracture: Diagnostic pitfalls and review of literature. Injury. 2015;46(9):1856-1859. doi:10.1016/j.injury.2015.04.025

12. Mehanna P, Mehanna D, Cronin A. White-eyed blow-out fracture: Another look. Emerg Med Australas. 2009;21(3):229-232. doi:10.1111/ j.1742-6723.2009.01186.x

13. Mehta N, Butala P, Bernstein MP. The imaging of maxillofacial trau$\mathrm{ma}$ and its pertinence to surgical intervention. Radiol Clin North Am. 2012;50(1):43-57. doi:10.1016/j.rcl.2011.08.005

14. Andrews BT, Jackson AS, Nazir N, Hromas A, Sokol JA, Thurston TE. Orbit fractures: Identifying patient factors indicating high risk for ocular and periocular injury. Laryngoscope. 2016;126(Suppl 4):S5-S11. doi:10.1002/lary.25805

15. Ho TQ, Jupiter D, Tsai JH, Czerwinski M. The incidence of ocular injuries in isolated orbital fractures. Ann Plast Surg. 2017;78(1):59-61. doi:10.1097/SAP.0000000000000748

16. Malik AH, Shah AA, Ahmad I, Shah BA. Ocular injuries in patients of zygomatico-complex (ZMC) fractures. J Maxillofac Oral Surg. 2017;16(2):243-247. doi:10.1007/s12663-016-0907-5

17. Peacock ZS, Boulos T, Miller JB, Gardiner MF, Chuang SK, Troulis MJ. Orbital fractures and ocular injury: Is a postoperative ophthalmology examination necessary? J Oral Maxillofac Surg. 2014;72(8):1533-1540. doi:10.1016/j.joms.2014.03.008

18. Ross M, El-Haddad C, Deschênes J. Ocular injury in orbital fractures at a level I trauma center. Can J Ophthalmol. 2017;52(50):499-502. doi:10.1016/j.jcjo.2017.01.013

19. Catherine $Z$, Courvoisier DS, Scolozzi P. Is the pure and impure distinction of orbital fractures clinically relevant with respect to ocular and periocular injuries? A retrospective study of 473 patients. J Craniomaxillofac Surg. 2019;47(12):1935-1942. doi:10.1016/j.jcms.2019.10.001

20. Jazayeri HE, Khavanin N, Yu JW, et al. Does early repair of orbital fractures result in superior patient outcomes? A systematic review and meta-analysis. J Oral Maxillofac Surg. 2020;78(4):568-577. doi:10.1016/j.joms.2019.09.025

21. Cohen SM, Garrett CG. Pediatric orbital floor fractures: Nausea/ vomiting as signs of entrapment. Otolaryngol Head Neck Surg. 2003;129(1):43-47. doi:10.1016/s0194-5998(03)00487-x

22. Baek SH, Lee EY. Clinical analysis of internal orbital fractures in children. Korean J Ophthalmol. 2003;17(1):44-49. doi:10.3341/ kjo.2003.17.1.44
23. Jordan DR, Allen LH, White J, Harvey J, Pashby R, Esmaeli B. Intervention within days for some orbital floor fractures: The whiteeyed blow-out. Ophthalmic Plast Reconstr Surg. 1998;14(6):379-390. doi:10.1097/00002341-199811000-00001

24. Young SM, Kim YD, Kim SW, et al. Conservatively treated orbital blowout fractures: Spontaneous radiologic improvement. Ophthalmology. 2018;125(6):938-944. doi:10.1016/j.ophtha.2017.12.015

25. Kang $\mathrm{DH}$. Orbital wall restoring surgery with primary orbital wall fragments in blowout fracture. Arch Craniofac Surg. 2019;20(6):347-353. doi:10.7181/acfs.2019.00724

26. Koltai PJ, Amjad I, Meyer D, Feustel PJ. Orbital fractures in children. Arch Otolaryngol Head Neck Surg. 1995;121(12):1375-1379. doi:10.1001/archotol.1995.01890120033006

27. Joshi S, Kassira W, Thaller SR. Overview of pediatric orbital fractures. J Craniofac Surg. 2011;22(40):1330-1332. doi:10.1097/ SCS.0b013e31821c9365

28. SuY, Shen Q, Lin M, Fan X.Diplopia of pediatric orbital blowout fractures: A retrospective study of 83 patients classified by age groups. Medicine (Baltimore). 2015;94(4):e477. doi:10.1097/MD.0000000000000477

29. Egbert JE, May K, Kersten RC, Kulwin DR. Pediatric orbital floor fracture: Direct extraocular muscle involvement. Ophthalmology. 2000;107(10):1875-1879. doi:10.1016/s0161-6420(00)00334-1

30. Gerber B, Kiwanuka P, Dhariwal D. Orbital fractures in children: A review of outcomes. Br J Oral Maxillofac Surg. 2013;51(8):789-793. doi:10.1016/j.bjoms.2013.05.009

31. Matteini C, Renzi G, Becelli R, Belli E, lannetti G. Surgical timing in orbital fracture treatment: Experience with 108 consecutive cases. J Craniofac Surg. 2004;15(1):145-150. doi:10.1097/00001665-200401000-00035

32. Oh SA, Aum JH, Kang DH, Gu JH. Change of the orbital volume ratio in pure blow-out fractures depending on fracture location. J Craniofac Surg. 2013;24(4):1083-1087. doi:10.1097/SCS.0b013e31828b6c2d

33. Choi JS, Oh SY, Shim HS. Correction of post-traumatic enophthalmos with anatomical absorbable implant and iliac bone graft. Arch Craniofac Surg. 2019;20(6):361-369. doi:10.7181/acfs.2019.00451

34. Liss J, StefkoST, Chung WL. Orbital surgery:State of the art. OralMaxillofac Surg Clin North Am. 2010;22(1):59-71. doi:10.1016/j.coms.2009.11.006

35. Kontio R, Lindqvist C. Management of orbital fractures. Oral Maxillofac Surg Clin North Am. 2009;21(2):209-220,vi. doi:10.1016/j.coms.2008.12.012

36. Wolff J, Sándor GKB, Pyysalo M, Miettinen A, Koivumäki AV, Kainulainen VT. Late reconstruction of orbital and naso-orbital deformities. Oral Maxillofac Surg Clin North Am. 2013;25(4):683-695. doi:10.1016/j.coms.2013.07.008

37. Kozakiewicz M, Elgalal M, Loba $P$, et al. Clinical application of 3D prebent titanium implants for orbital floor fractures. J Craniomaxillofac Surg. 2009;37(4):229-234. doi:10.1016/j.jcms.2008.11.009 